Article

\title{
Norcyperone, a Novel Skeleton Norsesquiterpene from Cyperus rotundus $\mathrm{L}$.
}

Yan Xu ${ }^{1}$, Hong-Wu Zhang ${ }^{1}$, Chang-Yuan Yu ${ }^{2, *}$, Yang Lu ${ }^{3}$, Ying Chang ${ }^{3}$, and Zhong-Mei Zou ${ }^{1,}$ *

1 Institute of Medicinal Plant Development, Chinese Academy of Medical Sciences and Peking Union Medical College, Beijing 100193, P. R. China; E-mail: xuyantea@163.com (Y.X.), hongwuzhang77@hotmail.com (H-W.Z.)

2 College of Life Science and Technology, Beijing University of Chemical Technology, Beijing 100029, P. R. China; E-mail: yucy@mail.buct.edu.cn (C-Y. Y.)

3 Institute of Materia Medica, Chinese Academy of Medical Sciences and Peking Union Medical College, Beijing 100050, P. R. China; E-mail: luy@imm.ac.cn (Y. L.),

* Authors to whom correspondence should be addressed: E-mail: zmzou@implad.ac.cn (Z-M. Zou), yucy@mail.buct.edu.cn (C-Y. Y.); Tel: +86 -10-62899756; Fax: +86 -10-62899756.

Received: 21 August 2008; in revised form: 25 September 2008 / Accepted: 26 September 2008 / Published: 10 October 2008

\begin{abstract}
A novel norsesquiterpene, named norcyperone (1), and three known compounds: (-)-clovane-2,9-diol (2), rosenonolactone (3), and 5 $\alpha, 8 \alpha$-epidioxy-(20S,22E,24R)-ergosta6,22-dien-3 $\beta$-ol (4) were isolated from the rhizomes of Cyperus rotundus $\mathrm{L}$. The structure of 1 was elucidated as 8,11,11-trimethylbicyclo[5.3.1]undecane-5 $\alpha, 8 \alpha$-epoxy-3-one on the basis of extensive spectroscopic analyses, including 1D- and 2D-NMR, MS experiments, and single-crystal X-ray diffraction. This is the first report of a 8,11,11trimethyl- bicyclo[5.3.1] undecane-3-one type norsesquiterpene with a tetrahydrofuran ring at $\mathrm{C}-5$ and $\mathrm{C}-8$.
\end{abstract}

Keywords: Cyperus rotundus L.; norsesquiterpene; norcyperone; bicyclo[5.3.1]undecane3-one 


\section{Introduction}

The rhizomes of Cyperus rotundus L. have been used in traditional Chinese medicine as an estrogenic and anti-inflammatory agent for the treatment of women's diseases and also used for treatment of stomach ache and bowel disorders [1]. The extract of the rhizomes of C. rotundus L. showed anti-diabetic activity [2], acetylcholinesterase inhibitory activity [3] and antidiarrhoeal activity [4], as well as inhibition of nitric oxide and superoxide production [5]. Previous phytochemical studies on $C$. rotundus $\mathrm{L}$. have led to the identification of more than 60 sesquiterpenes with a diversity of skeletons [6, 7] besides flavonoids, furochromones, triterpenes and sterols [8,9]. In the course of our phytochemical investigation of this species, a novel norsesquiterpene 1, named norcyperone, together with three known compounds: (-)-clovane-2,9-diol (2), rosenonolactone (3), and $5 \alpha, 8 \alpha$ epidioxy-(20S, 22E,24R)-ergosta-6,22-dien-3 $\beta$-ol (4) were isolated from the rhizomes of $C$. rotundus L. Herein we report the isolation and structural elucidation of these compounds.

\section{Results and Discussion}

The $95 \%$ EtOH extract of dried and powdered rhizomes of C. rotundus L. was suspended in $\mathrm{H}_{2} \mathrm{O}$ and then extracted successively with petroleum ether, $\mathrm{CH}_{2} \mathrm{Cl}_{2}$, EtOAc and n-BuOH, The $\mathrm{CH}_{2} \mathrm{Cl}_{2}$ soluble fraction was separated by repeated column chromatography to afford a novel norsesquiterpene, norcyperone (1) and three known compounds 2-4 (Figure 1).Compounds 2, 3 and 4 were identified as (-)-clovane-2,9-diol (2) [10], rosenonolactone (3) [11], and 5 $\alpha, 8 \alpha$-epidioxy-(20S,22E,24R)-ergosta6,22-dien-3 $\beta$-ol (4) [12-13] by comparing their physical and spectroscopic data with those reported in the literatures.

Figure 1. Structures of compounds 1-4.

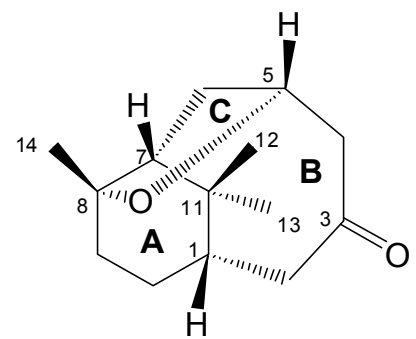

1

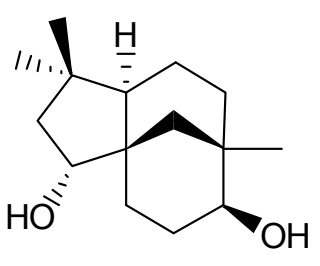

2

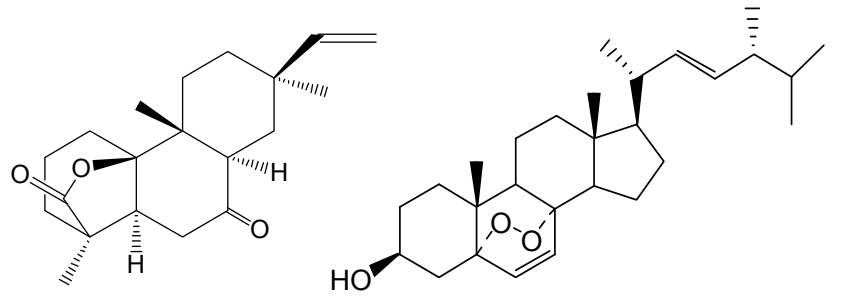

3
4

Compound 1 was obtained as colourless needles in $\mathrm{CH}_{2} \mathrm{Cl}_{2}, \mathrm{mp} 146-148^{\circ} \mathrm{C},[\alpha]^{20}$, D $-54.3^{\circ}(c=0.09$, $\mathrm{CH}_{2} \mathrm{Cl}_{2}$ ). Its IR spectrum showed a strong carbonyl group absorption at $1693 \mathrm{~cm}^{-1}$. The molecular formula of 1 was assigned as $\mathrm{C}_{14} \mathrm{H}_{22} \mathrm{O}_{2}$ by HR-ESI-MS $\left(\mathrm{m} / \mathrm{z} 245.1514[\mathrm{M}+\mathrm{Na}]^{+}\right.$, calcd. 245.1512 $\left.[\mathrm{M}+\mathrm{Na}]^{+}\right)$, with four degrees of unsaturation. The complete assignment of all protons and carbons for $\mathbf{1}$ was made by ${ }^{1} \mathrm{H}-\mathrm{NMR},{ }^{13} \mathrm{C}-\mathrm{NMR},{ }^{1} \mathrm{H}-{ }^{1} \mathrm{H}$ COSY, HMQC and $\mathrm{HMBC}$ (Table 1). Its ${ }^{13} \mathrm{C}-\mathrm{NMR}$ spectrum gave 14 carbon signals including two oxygenated ones at $\delta_{\mathrm{C}} 83.8$ and 72.2 , respectively, and a ketone carbon signal at at $\delta_{\mathrm{C}}$ 211.3. The remaining carbon signals were three methyl groups, five methylene units, two methine units and one quaternary carbon. The ${ }^{1} \mathrm{H}-\mathrm{NMR}$ spectrum of $\mathbf{1}$ exhibited 
three singlet methyls at $\delta_{\mathrm{H}} 1.11,1.14$ and 1.17, as well as a proton signal of oxygen-bearing carbon at $\delta_{\mathrm{H}}$ 4.39. The ${ }^{1} \mathrm{H}-{ }^{1} \mathrm{H}$ COSY correlations between $\mathrm{H}-1 / \mathrm{H}-2 \mathrm{a}, 2 \mathrm{~b}, \mathrm{H}-1 / \mathrm{H}-10 \mathrm{a}, 10 \mathrm{~b}, \mathrm{H}-9 \mathrm{~b} / \mathrm{H}-10 \mathrm{~b}, \mathrm{H}-5 / \mathrm{H}-$ $4 \mathrm{a}, 4 \mathrm{~b}, \mathrm{H}-6 \mathrm{a} / \mathrm{H}-5,7$, and H-6b/H-5, 7 revealed partial structures shown by bold lines in Figure 2.

Figure 2. Key HMBC and ${ }^{1} \mathrm{H}-{ }^{1} \mathrm{H}$ COSY correlations of $\mathbf{1}$.

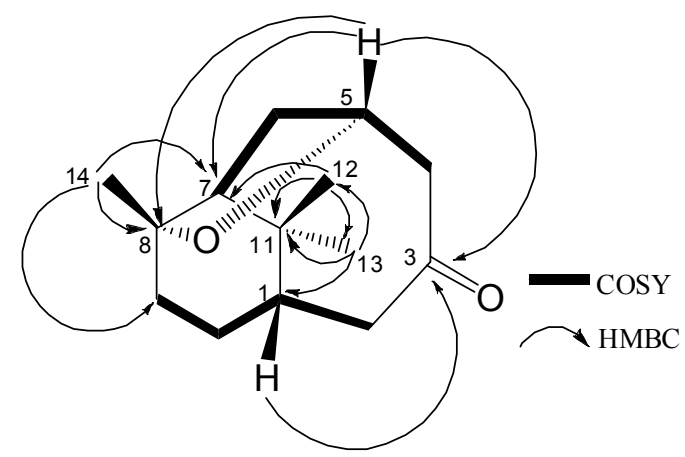

The location of the ketone carbonyl group was established at C-3 by the HMBC correlations of the carbonyl carbon signal $\left(\delta_{\mathrm{C}} 211.3\right)$ with the resonances of $\mathrm{H}-1, \mathrm{H}-2, \mathrm{H}-4$ and $\mathrm{H}-5$, while the protons of the methyl singlet at $\delta_{\mathrm{H}} 1.11$ and 1.14 gave HMBC correlations to $\delta_{\mathrm{C}} 38.6(\mathrm{C}-1), \delta_{\mathrm{C}} 50.6(\mathrm{C}-7)$, and $\delta_{\mathrm{C}}$ 35.1(C-11) suggesting the two geminal methyls linked at $\mathrm{C}-11$. In turn, the HMBC spectrum exhibited correlations of the methyl protons $\left(\delta_{\mathrm{H}} 1.17\right)$ with $\delta_{\mathrm{C}} 50.6(\mathrm{C}-7), \delta_{\mathrm{C}} 83.8(\mathrm{C}-8)$, and $\delta_{\mathrm{C}} 30.3(\mathrm{C}-9)$, in good agreement with a methyl group linked at $\mathrm{C}-8$. The presence of a tetrahydrofuran ring was deduced by the molecular formula as well as the HMBC correlation between the proton of oxygenbearing carbon at $\delta_{\mathrm{H}} 4.39(\mathrm{H}-5)$ and $\mathrm{C}-8$ (Figure 2). All above data indicated that compound 1 was a 8 , 11, 11-trimethyl- bicyclo[5.3.1] undecane-3-one type norsesquiterpene with a tetrahydrofuran ring at C-5 and C-8.

Figure 3. Key NOESY correlations of 1.

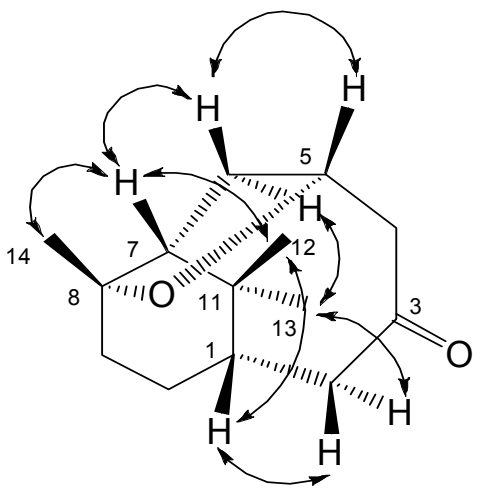

The relative stereochemistry of $\mathbf{1}$ was determined on the basis of a NOESY spectrum. The NOESY correlations between $\mathrm{H}-1 / \mathrm{CH}_{3}-12, \mathrm{CH}_{3}-12 / \mathrm{H}-7, \mathrm{H}-7 / \mathrm{CH}_{3}-14, \mathrm{H}-5 / \mathrm{H}-6 \mathrm{a}, \mathrm{H}-6 \mathrm{a} / \mathrm{H}-7$ suggested that all these atoms were in $\beta$-orientation (Figure 3), which further confirmed by single-crystal X-ray diffraction (Figure 4). The crystal structure showed a six-numbered ring $A$ in 'twist boat' conformation, an eight-numbered ring $B$ in 'boat' conformation, and a five-numbered tetrahydrofuran ring $C$ in an 'envelope' conformation, in which rings $A$ and $C$ are cis-fused. Thus, the structure of 1 
was elucidated as 8,11,11-trimethylbicyclo[5.3.1] undecane-5 $\alpha, 8 \alpha$-epoxy-3-one $(1 \beta$-H,7 $\beta$-H), named norcyperone.

Figure 4. X-ray structure of compound 1.

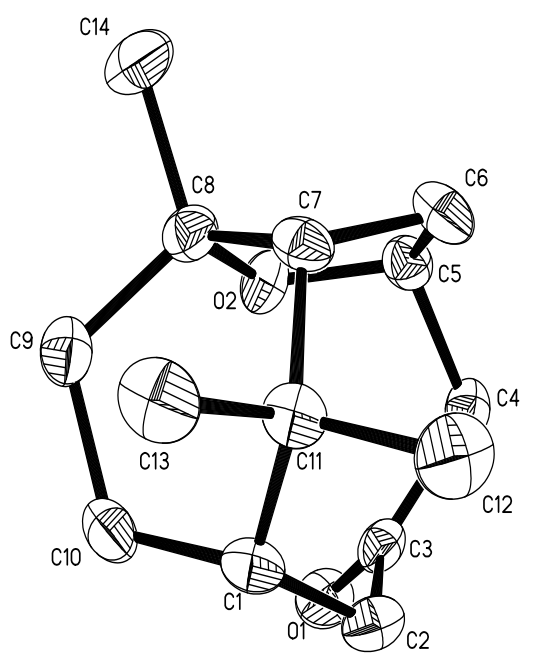

Table 1. The NMR data of compound $\mathbf{1}^{\mathrm{a}}$.

\begin{tabular}{clll}
\hline Position & \multicolumn{1}{c}{${ }^{1} \mathrm{H}-\mathrm{NMR}$} & ${ }^{13} \mathrm{C}-\mathrm{NMR}$ & $\mathrm{HMBC}(\mathrm{H} \rightarrow \mathrm{C})$ \\
\hline 1 & $1.88(1 \mathrm{H}, \mathrm{m})$ & 38.6 & $\mathrm{C}-3,7,9,12,13$ \\
$2 \mathrm{a}$ & $2.86(1 \mathrm{H}, \mathrm{dd}, 12.6,1.8)$ & 47.9 & $\mathrm{C}-1,3,10$ \\
$2 \mathrm{~b}$ & $2.34(1 \mathrm{H}, \mathrm{ddd}, 12.6,7.8,1.2)$ & & $\mathrm{C}-1,3,4,10,11$ \\
3 & - & 211.3 & \\
$4 \mathrm{a}$ & $2.88(1 \mathrm{H}, \mathrm{ddd}, 13.2,7.8,1.8)$ & 52.6 & $\mathrm{C}-2,3,5,6$ \\
$4 \mathrm{~b}$ & $2.62(1 \mathrm{H}, \mathrm{dd}, 13.2,3.0)$ & & $\mathrm{C}-3,5,6$ \\
5 & $4.39(1 \mathrm{H}, \mathrm{ddt}, 10.2,7.2,1.8)$ & 72.2 & $\mathrm{C}-3,7,8$ \\
$6 \mathrm{a}$ & $2.64(1 \mathrm{H}, \mathrm{dd}, 14.4,10.2)$ & 35.4 & $\mathrm{C}-4,5,7,11$ \\
$6 \mathrm{~b}$ & $2.18(1 \mathrm{H}, \mathrm{br}, 14.4)$ & & $\mathrm{C}-4,7,8,11$ \\
7 & $1.77(1 \mathrm{H}, \mathrm{d}, 10.2)$ & 50.6 & $\mathrm{C}-1,5,12,14$ \\
8 & - & 83.8 & \\
$9 \mathrm{a}$ & $1.85(1 \mathrm{H}, \mathrm{m})$ & 30.3 & $\mathrm{C}-1,7,8,10$ \\
$9 \mathrm{~b}$ & $1.79(1 \mathrm{H}, \mathrm{m})$ & & $\mathrm{C}-8,10$ \\
$10 \mathrm{a}$ & $1.94(1 \mathrm{H}, \mathrm{m})$ & 19.6 & $\mathrm{C}-1,2,8,9$ \\
$10 \mathrm{~b}$ & $1.90(1 \mathrm{H}, \mathrm{m})$ & & $\mathrm{C}-1,2,8,9$ \\
11 & - & 35.1 & \\
12 & $1.14(3 \mathrm{H}, \mathrm{s})$ & 34.3 & $\mathrm{C}-1,7,11,13$ \\
13 & $1.11(3 \mathrm{H}, \mathrm{s})$ & 28.4 & $\mathrm{C}-1,7,11,12$ \\
14 & $1.17(3 \mathrm{H}, \mathrm{s})$ & 30.1 & $\mathrm{C}-7,8,9$ \\
\hline
\end{tabular}

${ }^{\text {a }} \mathrm{H}-\mathrm{NMR}(600 \mathrm{MHz}),{ }^{13} \mathrm{C}-\mathrm{NMR}(150 \mathrm{MHz})$ spectra of compound 1 were measured in $\mathrm{CDCl}_{3}$ on a Varian Inova-600 MHz spectrometer, $\delta$ in ppm, $J$ in $\mathrm{Hz}$. 


\section{Conclusions}

A novel skeleton norsesquiterpene, norcyperone, together with three known compounds 2-4 were isolated from the rhizomes of $C$. rotundus L. Although a 8,11,11-trimethylbicyclo[5.3.1] undecane has been reported as a synthetic intermediate derived in the course of synthesis of the taxane-AB-fragment with a spiro-cyclopropyl group [14], this is the first report of a 8,11,11-trimethylbicyclo[5.3.1] undecane-3-one type norsesquiterpene with a tetrahydrofuran ring at C-5 and C-8. Compounds 2-4 were isolated from the genus Cyperus for the first time. These findings enrich our knowledge of the chemical constituents of C. rotundus $\mathrm{L}$.

\section{Experimental}

\section{General}

Melting points were determined on Fisher-Johns Melting Point Apparatus and are uncorrected. IR spectra were measured with a Bruker IFS-55 infrared spectrometer $(\mathrm{KBr})$. Optical rotations were recorded on a Perkin-Elmer 241 automatic recording spectropolarimeter. EI mass spectra were recorded on a Zabspec E mass spectrometer. HR-ESI-MS was taken on a LTQ Orbitrap ${ }^{\mathrm{TM}}$ Mass spectrometer. Column chromatography was performed over Silica gel (200-300 mesh) (Qingdao Marine Chemical Factory) and Sephadex LH-20 (Pharmacia). Nuclear magnetic resonance (NMR) spectra were measured on a Varian Inova-600 spectrometer operating at $600 \mathrm{MHz}\left({ }^{1} \mathrm{H}\right)$ and $150 \mathrm{MHz}$ $\left({ }^{13} \mathrm{C}\right)$, respectively.

\section{Plant material}

The dried rhizomes of $C$. rotundus L. were collected from Dabieshan Mountains of Anhui Province, P.R. China in Sep. 2006. A voucher specimen (No: 20060825) was authenticated by Prof. Yulin Lin and deposited at the Herbarium of the Institute of Medicinal Plant Development, Chinese Academy of Medical Sciences and Peking Union Medical College.

\section{Extraction and isolation}

The dried and powdered rhizomes of $C$. rotundus L. (15 kg) were extracted with $95 \%$ EtOH three times under reflux, and the solvent was evaporated in vacuo. The residues were partitioned in $\mathrm{H}_{2} \mathrm{O}$ and extracted successively with petroleum ether, $\mathrm{CH}_{2} \mathrm{Cl}_{2}$, EtOAc and n-BuOH. The $\mathrm{CH}_{2} \mathrm{Cl}_{2}$ extract (158 g) was submitted to column chromatography on silica gel eluting with petroleum ester/EtOAc (50:1 to $0: 1)$ to afford eight fractions $\left(\mathrm{F}_{1}-\mathrm{F}_{8}\right)$. Fraction $\mathrm{F}_{2}(22 \mathrm{~g})$ was further separated by silica gel column chromatography eluting with petroleum ether/acetone $(20: 1$ to $2: 1)$ to give 8 fractions $\left(F_{2 a}-F_{2 h}\right)$. Fraction $\mathrm{F}_{2 \mathrm{~d}}$ was purified by silica gel column chromatography eluting with petroleum ether/acetone (10:1) and Sephadex LH-20 eluted with $\mathrm{CH}_{2} \mathrm{Cl}_{2} / \mathrm{MeOH}(1: 1)$ to obtain 3 (14 mg). Fractions $\mathrm{F}_{2 \mathrm{f}}$ was purified by silica gel column chromatography eluting with petroleum ester/acetone (4:1) to obtain 4 (24 mg). $F_{5}$ (18 g) was further chromatographed on silica gel eluted with petroleum ester/acetone (6:1 
to $1: 1)$ to give 10 fractions $\mathrm{F}_{5 \mathrm{a}}-\mathrm{F}_{5 \mathrm{j}}$. Fraction $\mathrm{F}_{5 \mathrm{~b}}$ was purified by silica gel eluted with petroleum ether /acetone (5:1) and Sephadex LH-20 eluted with $\mathrm{CH}_{2} \mathrm{Cl}_{2} / \mathrm{MeOH}$ (1:1) to obtain 1 (16 mg). Fraction $\mathrm{F}_{5 \mathrm{e}}$ was purified by Sephadex LH-20 eluting with $\mathrm{CH}_{2} \mathrm{Cl}_{2} / \mathrm{MeOH}(1: 1)$ to obtain 2 (10 mg).

Norcyperone (1): colorless needles; mp $146-148^{\circ} \mathrm{C} ;[\alpha]^{20}$, D $-54.3^{\circ}\left(\mathrm{c}=0.09, \mathrm{CH}_{2} \mathrm{Cl}_{2}\right.$ ); HR-ESI-MS $m / z$ $245.1514[\mathrm{M}+\mathrm{Na}]^{+}$, calcd. $245.1512[\mathrm{M}+\mathrm{Na}]^{+}$. IR $v_{\max } \mathrm{cm}^{-1}: 2968,2935,2881,1693,1371,1066 ;{ }^{1} \mathrm{H}-$ NMR and ${ }^{13} \mathrm{C}-\mathrm{NMR}$ data: see Table 1.

(-)-Clovane-2, 9-diol (2): colourless needles; mp 162-164 C; EI-MS m/z: 238(M), 220, 182, 164, 135 , 107, 93, 41. ${ }^{1} \mathrm{H}-\mathrm{NMR}\left(\mathrm{CD}_{3} \mathrm{COCD}_{3}\right) \delta_{\mathrm{H}:} 0.85\left(3 \mathrm{H}, s, \mathrm{CH}_{3}-13\right), 0.91\left(3 \mathrm{H}, s, \mathrm{CH}_{3}-15\right), 1.01\left(3 \mathrm{H}, s, \mathrm{CH}_{3}-\right.$ 14), 3.22 (1H, $m, \mathrm{H}-9), 3.72(1 \mathrm{H}, \mathrm{m}, \mathrm{H}-2), 1.43(1 \mathrm{H}, m, \mathrm{H}-5) ;{ }^{13} \mathrm{C}-\mathrm{NMR}\left(\mathrm{CD}_{3} \mathrm{COCD}_{3}\right) \delta_{\mathrm{C}}: 45.4(\mathrm{C}-1)$, 80.8 (C-2), 48.5 (C-3), 37.6 (C-4), 51.5 (C-5), 34.1 (C-6), 21.5 (C-7), 35.4 (C-8), 74.9 (C-9), 27.2 (C10), 27.5 (C-11), 36.4 (C-12), 25.8 (C-13), 31.9 (C-14), 29.2 (C-15).

Rosenonolactone (3): white needles, mp 224-226 ${ }^{\circ} \mathrm{C}$; EI-MS m/z: 316(M), 301, 220, 163, 108, 93, 41. ${ }^{1} \mathrm{H}-\mathrm{NMR}\left(\mathrm{CDCl}_{3}\right) \delta_{\mathrm{H}:} 0.95\left(3 \mathrm{H}, s, \mathrm{CH}_{3}-20\right), 0.97\left(3 \mathrm{H}, s, \mathrm{CH}_{3}-17\right), 1.13\left(3 \mathrm{H}, s, \mathrm{CH}_{3}-18\right), 4.92(1 \mathrm{H}, d d$, $J=10.8,0.6 \mathrm{~Hz}, \mathrm{H}-16 \mathrm{a}), 4.99$ (1H, $d d, J=17.4,1.2 \mathrm{~Hz}, \mathrm{H}-16 \mathrm{~b}), 5.83(1 \mathrm{H}, d d, J=17.4,10.8 \mathrm{~Hz}, \mathrm{H}-15)$;

${ }^{13} \mathrm{C}-\mathrm{NMR}\left(\mathrm{CDCl}_{3}\right) \delta_{\mathrm{C}}: 30.3(\mathrm{C}-1), 19.8(\mathrm{C}-2), 35.5$ (C-3), $47.3(\mathrm{C}-4), 50.9(\mathrm{C}-5), 35.8$ (C-6), $210.2(\mathrm{C}-$ 7), 47.4 (C-8), 38.9 (C-9), 86.9 (C-10), 30.8 (C-11), 31.4 (C-12), 35.1 (C-13), 31.7 (C-14), 149.6 (C15), 109.9 (C-16), 21.9 (C-17), 16.9 (C-18), 179.2 (C-19), 16.8 (C-20).

$5 \alpha, 8 \alpha$-Epidioxy-(20S,22E,24R)-ergosta-6,22-dien-3 $\beta$-ol (4): colourless needles; mp $155-157^{\circ} \mathrm{C}$; EIMS m/z: $428(\mathrm{M}), 396,251,152,107,93,81,69 ;{ }^{1} \mathrm{H}-\mathrm{NMR}\left(\mathrm{CDCl}_{3}\right) \delta_{\mathrm{H}:} 6.50(1 \mathrm{H}, d, J=8.5 \mathrm{~Hz}, \mathrm{H}-6)$, $6.24(1 \mathrm{H}, d, J=8.5 \mathrm{~Hz}, \mathrm{H}-7), 5.21(1 \mathrm{H}, d d, J=15.5,8.0 \mathrm{~Hz}, \mathrm{H}-23), 5.14(1 \mathrm{H}, d d, J=15.5,8.0 \mathrm{~Hz}, \mathrm{H}-22)$, $3.97(1 \mathrm{H}, m, \mathrm{H}-3), 1.00(3 \mathrm{H}, d, J=7.0 \mathrm{~Hz}, \mathrm{H}-21), 0.91(3 \mathrm{H}, d, J=7.0 \mathrm{~Hz}, \mathrm{H}-28), 0.88$ (3H, $s, \mathrm{H}-19)$, $0.84(3 \mathrm{H}, s, \mathrm{H}-18), 0.82(3 \mathrm{H}, d, J=5.0 \mathrm{~Hz}, \mathrm{H}-26), 0.81(3 \mathrm{H}, d, J=3.0 \mathrm{~Hz}, \mathrm{H}-27) ;{ }^{13} \mathrm{C}-\mathrm{NMR}\left(\mathrm{CDCl}_{3}\right) \delta_{\mathrm{C}}$ : 34.7 (C-1), 30.1 (C-2), 66.5 (C-3), 36.9 (C-4), 82.1 (C-5), 135.4 (C-6), 130.8 (C-7), 79.4 (C-8), 51.1 (C-9), 36.8 (C-10), 23.4 (C-11), 39.4 (C-12), 44.6 (C-13), 51.7 (C-14), 20.6 (C-15), 28.6 (C-16), 56.2 (C-17), 13.0 (C-18), 18.2 (C-19), 39.9 (C-20), 20.9 (C-21), 135.2 (C-22), 132.3 (C-23), 42.8 (C-24), 33.1 (C-25), 19.9 (C-26), 19.6 (C-27), 17.6 (C-28).

\section{Crystallographic Data}

Crystallographic data for 1: formula: $\mathrm{C}_{14} \mathrm{H}_{22} \mathrm{O}_{2}$; molecular weight: 222.32; monoclinic, space group $P 2{ }_{1} 2_{1} 2_{1}, a=7.450$ (15), $b=8.691(17), c=18.981$ (4) $\AA ; V=1228.8(4) \AA^{3}, Z=4, d=1.202 \mathrm{~g} / \mathrm{cm}^{3}$; crystal dimensions, $0.15 \times 0.15 \times 0.30 \mathrm{~mm}$. The measurements were performed on a MAC DIP-2030K diffractometer with a graphite monochromator $\left(\omega-2 \theta\right.$ scans, $\left.2 \theta \max =50.0^{\circ}\right), \operatorname{MoKa}$ radiation. The total number of independent and observed reflections was $2423\left(|F|^{2} \geq 2 \sigma|F|^{2}\right)$. The crystal structure was solved by direct methods using SHELXS-97, expanded using difference Fourier techniques, and refined with NOMCSDP using full-matrix least-squares calculations. Final indices: $R 1=0.0395, w R 2$ $=0.0991, S=1.038$. Crystallographic data for $\mathbf{1}$ has been deposited at the Cambridge Crystallographic Data Center. CCDC 694682 contains the supplementary crystallographic data for this paper. These 
data can be obtained free of charge via www.ccdc.cam.ac.uk/conts/retrieving.html (or from the CCDC, 12 Union Road, Cambridge CB2 1EZ, UK; fax: +44 1223 336033; e-mail: deposit@ccdc.cam.ac.uk).

\section{Acknowledgements}

This work was supported by the National Natural Science Foundation of China (30772711) and the Scientific Research Foundation for the Returned Overseas Chinese Scholars, State Education Ministry of China.We are grateful to Professor Yulin Lin, Institute of Medicinal Plant Development, Chinese Academy of Medical Sciences and Peking Union Medical College for the identification of C. rotundus L. We are also thankful to Mr. He-bin Chen, the Academy of Military Medical Sciences for NMR measurements.

\section{References}

1. Jiangsu New Medical College. Dictionary of Chinese Materia Medica; Shanghai People's Publishing House: Shanghai, P.R.China, 1971; pp. 3441-3443.

2. Raut, N. A.; Gaikwad, N. J. Antidiabetic activity of hydro-ethanolic extract of Cyperus rotundus in alloxan induced diabetes in rats. Fitoterapia 2006, 77, 585-588.

3. Sharma, R.; Gupta, R. Cyperus rotundus extract inhibits acetylcholinesterase activity from animal and plants as well as inhibits germination and seedling growth in wheat and tomato. Life Sci. 2007, 80, 2389-2392.

4. Uddin, S. J.; Mondal, K.; Shilpi, J. A.; Rahman, M. T. Antidiarrhoeal activity of Cyperus rotundus. Fitoterapia 2006, 77, 134-136.

5. Seo, W. G.; Pae, H. O.; Oh, G. S.;Chai, K. Y.; Kwon, T. O.; Yun, Y. G.; Kim, N. Y.; Chung, H. $\mathrm{T}$. Inhibitory effects of methanol extract of Cyperus rotundus rhizomes on nitric oxide and superoxide productions by murine macrophage cell line, RAW 264.7 cells. J. Ethnopharmacol. 2001, 76, 59-64.

6. Huang, X. F.; Peng, G. P. Research progress on chemical components and the pharmacology of the rhizomes of Cyperus rotundus L. J. Chin. Med. Mate. 2003, 26, 65-68.

7. Jeong, S. J.; Miyamoto, T.; Inagaki, M.; Kim, Y.C.; Higuchi, R. Rotundines A-C, three novel sesquiterpene alkaloids from Cyperus rotundus. J. Nat. Prod. 2000, 63, 673-675.

8. Weehen, H.; Nkunya, M. H. H.; Bray, D. H.; Mwasumbi, L. B., Kinabo, L. S., and Kilimali, A. E. B.; and Wijnberg, B. P. A. Antimalarial activity of Tanzanian plants. Part 2. Antimalarial compounds containing an $\alpha, \beta$-unsaturated carbonyl moiety from Tanzanian medicinal plants. Planta Med. 1990, 56, 371-373.

9. Sayed, H. M.; Mohamed, M.H.; Farag, S.F.; Mohamed, G.A.; Proksch, P. A new steroid glycoside and furochromones from Cyperus roundus L. Nat. Prod. Res. 2007, 21, 343-350.

10. Tsui, W. Y.; Brown, G. D. Sesquiterpenes from Baeckea frutescens. J. Nat. Prod. 1996, 59, 10841086.

11. Loukaci, A.; Kayser, O.; Bindseil, K. U.; Siems, K.; Frevert, J.; Abreu, P. M. New trichothecenes isolated from Holarrhena floribunda. J. Nat. Prod. 2000, 63, 52-56. 
12. Ishizuka, T.; Yaoita, Y.; Kikuehi, M. Sterols from the fruit body of Grifola frondosa. Chem. Pharm. Bull. 1997, 45, 1756-1760.

13. Li, G. Y.; Li, B. W.; Liu, G. Y.; Zhang, G. L. Sterols from Aspergillus ocharceus 43. Chin. J. Appl. Environ. Biol. 2005, 11, 67-70.

14. Friese, J. C.; Schafer, H. J. Short synthesis of a taxane-AB-fragment with a spiro-cyclopropyl group. Synlett. 2002, 5, 814-816.

Sample Availability: Samples are available from the authors.

(C) 2008 by the authors; licensee Molecular Diversity Preservation International, Basel, Switzerland. This article is an open-access article distributed under the terms and conditions of the Creative Commons Attribution license (http://creativecommons.org/licenses/by/3.0/). 